\title{
Disruption of the $\beta_{2}$-integrin CD11d $\left(\alpha_{D} \beta 2\right)$ gene fails to protect against experimental autoimmune encephalomyelitis
}

\author{
Jillian E. Adams ${ }^{1}$, Matthew S. Webb ${ }^{1}$, Jane $\mathrm{Hu}^{1}$, Don Staunton ${ }^{3}$, and Scott R. Barnum ${ }^{1,2,{ }^{*}}$ \\ ${ }^{1}$ Department of Microbiology, University of Alabama at Birmingham, $84519^{\text {th }}$ St. S., BBRB/842, \\ Birmingham, AL, 35294 USA \\ ${ }^{2}$ Department of Neurology, University of Alabama at Birmingham, $84519^{\text {th }}$ St. S., BBRB/842, \\ Birmingham, AL, 35294 USA
}

${ }^{3}$ ICOS Pharmaceuticals, $2202120^{\text {th }}$ Ave. SE Bothell, WA, 98021 USA

\begin{abstract}
The fourth member of the $\beta_{2}$-integrin family of adhesion molecules, CD11d $\left(\alpha_{D} \beta_{2}\right)$, is expressed on a wide variety of immune cells, however its function in autoimmune diseases, including EAE remains unknown. We induced EAE in wild type and $\mathrm{CD} 11 \mathrm{~d}^{-/-} \mathrm{C} 57 \mathrm{BL} / 6$ mice using myelin oligodendrocyte glycoprotein $\left(\mathrm{MOG}_{35-55}\right)$ peptide. The clinical course and histopathology of EAE was identical in both groups of mice throughout the disease course. There were no significant differences in the infiltration of leukocyte subsets into the central nervous system or in the production of cytokines from $T$ cells isolated from the spleen or spinal cord from both groups of mice. Our data demonstrate that CD11d is not required for the development of EAE and, to date, is the only $\beta_{2}$-integrin molecule whose deletion does not result in attenuated disease.
\end{abstract}

\section{Keywords}

adhesion molecules; $\beta_{2}$-integrins; EAE; neuroimmunology

\section{Introduction}

A critical requirement for the development of multiple sclerosis (MS) and its animal model experimental autoimmune encephalomyelitis (EAE) is the trafficking of immune effector cells into the central nervous system (CNS). These cells include macrophages and antigen-specific $\mathrm{T}$ cells which can participate in lesion formation and, in turn, demyelination (Sospedra and Martin, 2005). There are several families of cellular adhesion molecules known to function in the trafficking of effector cells to sites of inflammation, including the CNS (Archelos et al., 1999; Butcher et al., 1999; Campbell et al., 1998; Engelhardt, 2006; von Andrian and Mackay, 2000). In MS, the most notable of these are the $\alpha_{4}$ integrins, specifically $\alpha_{4} \beta_{7}$ and $\alpha_{4} \beta_{1}$, since treatment with antibody to $\alpha_{4}$ reduces the development of new lesions, resulting in fewer clinical relapses (Miller et al., 2003). However inhibition of $\alpha_{4}$ integrins, by a variety of approaches, does not completely prevent disease, due most likely to the participation of other cellular adhesion molecules in the disease process (Engelhardt et al., 1998; Kent et al., 1995; Myers et al., 2005; Yednock et al., 1992).

*Address correspondence to: Dr. Scott R. Barnum, Department of Microbiology, University of Alabama at Birmingham, $84519^{\text {th }}$ St. S., BBRB/842, Birmingham, AL 35294, USA. Phone: (205) 934-4972; Fax: (205) 934-4985; sbarnum @uab.edu. 
In addition to the $\alpha_{4}$ integrins, members of the $\beta_{2}$-integrin family, in particular CD11a and $\mathrm{CD} 11 \mathrm{~b}$ have been shown to contribute to EAE, however the results have often been contradictory. For example, treatment with anti-CD11a antibody in EAE produced results ranging from disease inhibition to exacerbation (Cannella et al., 1993; Gordon et al., 1995; Welsh et al., 1993; Willenborg et al., 1996). Similarly, several studies have shown variable levels of protection in antibody-mediated inhibition of CD11b. Those studies demonstrating attenuated disease attributed protection largely to prevention of myelin phagocytosis (Brocke et al., 1999; Bruck, 1997; Bruck and Friede, 1990; Gordon et al., 1995; Huitinga et al., 1993; Smith, 1999). Studies using CD11b-deficient mice, have shown that CD11b expression on T cells is critical for disease development, independent of cell trafficking into the CNS or phagocytosis (Bullard et al., 2005). More recent studies using CD11c-deficient mice have also shown a protective phenotype in EAE compared to control mice (Bullard et al., submitted). In contrast to these three $\beta_{2}$-integrins family members, nothing is known regarding the role of CD11d in EAE.

Previous studies have demonstrated multiple roles for CD11d in immune responses including facilitation of macrophage activation and infiltration into inflamed tissues (Bao et al., 2004; Mabon et al., 2000; Saville et al., 2004), development of IgG complex induced lung injury (Shanley et al., 1998) and T cell proliferation (Wu et al., 2004). In a spinal cord injury model (SCI), treatment with antibody to CD11d markedly reduced neutrophil and macrophage infiltration leading to improved recovery and reduced secondary damage (Gris et al., 2005; Gris et al., 2004; Mabon et al., 2000). These results, combined with those demonstrating reduced cellular infiltration in CD11b-deficient mice during EAE, suggested to us that loss of CD11d-mediated trafficking mechanisms would prove beneficial in EAE. We show here that deletion of CD11d, in contrast to other members of the $\beta_{2}$-integrin family, has no effect on the development and progression of EAE. These data indicate that $\beta_{2}$-integrin functions are not redundant in EAE and suggest differential functions in acute versus chronic inflammation.

\section{Materials and Methods}

\section{Mice}

CD11 $\mathrm{d}^{-/-}$mice were generated through the replacement of exons 1 and 2 of the CD11d gene with a neomycin cassette as previously described (Wu et al., 2004). All CD11-deficient mice were backcrossed for at least six generations onto the C57BL/6 background. Inbred C57BL/6 mice were used as controls for all experiments. All studies were performed with approval from the University of Alabama at Birmingham Institutional Animal Care and Use Committee.

\section{EAE induction}

Control and $\mathrm{CD} 11 \mathrm{~d}^{-/-}$mice were immunized with MOG35-55 peptide as previously described (Szalai et al., 2002). MOG peptide was synthesized by standard 9-fluorenyl-methoxycarbonyl chemistry and was $>95 \%$ pure as determined by reversed-phase HPLC (Biosynthesis International). Briefly, on day 0 mice were injected subcutaneously with MOG35-55 emulsified in complete Freud's adjuvant. Pertussis toxin was injected intraperitoneally on day 0 and 2. Onset and progression of EAE symptoms were monitored daily using a standard clinical scale ranging from 0 to 6 as follows: 0 , asymptomatic; 1 , loss of tail tone; 2, flaccid tail; 3, incomplete paralysis of one or two hind limbs; 4, complete hind limb paralysis; 5, moribund; 6, dead. Mice scoring at least a 2 for more than 2 consecutive days were judged to have EAE. For each animal, a cumulative disease index (CDI) was calculated from the sum of the daily clinical scores observed between days 7 and 29 . 


\section{Isolation of Spinal Cord Leukocytes}

Spinal cords were removed from control and CD11 $\mathrm{d}^{-/-}$mice with active EAE (day 10 and 21) following saline perfusion and were ground through a cell strainer, washed in PBS, resuspended in 40\% Percoll, and layered on 70\% Percoll. After centrifugation at $2000 \mathrm{rpm}$ (RT, $25 \mathrm{~min}$ ), cells at the interface were removed, washed in PBS, and stained as described below.

\section{Flow Cytometry}

Cells obtained from spinal cords, draining lymph nodes, or spleens were incubated with antiCD16/32 (24G2, FcR block) to prevent nonspecific staining. Spinal cord leukocytes were stained with anti-CD45-FITC (30F11), anti-CD4-Sav-PerCP (GK1.5), anti-CD8-APC (53-6.7), anti-TNF- $\alpha$-PE (MP6-XT22), and anti-IFN- $\gamma$-FITC (XMG1.2; all from eBioscience). To determine if $\beta_{2}$-integrin expression changed during EAE on T cells or macrophages from $\mathrm{CD} 11 \mathrm{~d}^{-/-}$mice relative to control mice, cells were isolated from spleens or lymph nodes at day 21 post-immunization, stained with anti-CD16/32 as described above and then stained with anti-CD3-FITC (145-2C11), or F4/80-FITC (BM8) and anti-CD11a-PE (M17/4), CD11b Biotin-Sav-PercP (M1-70) or anti-CD11c-APC (HL3). Stained cells were analyzed using a FACSCalibur (BD Biosciences) and data was analyzed using CellQuest software (BD Biosciences).

\section{T cell proliferation and cytokine production}

Ag-specific T cell proliferation assays were performed as described previously (Szalai et al., 2002). Single-cell suspensions from spleens obtained 21 days after EAE induction were cultured in 96-well plates at $5 \times 10^{5}$ cells/well with increasing concentrations of MOG35-55 peptide or $3 \mathrm{ug} / \mathrm{ml}$ ConA in triplicate. After $48 \mathrm{~h}$, cultures were pulsed with $\left[{ }^{3} \mathrm{H}\right]$ thymidine for an additional $18 \mathrm{~h}$, and incorporation of thymidine was measured. The in-vitro cytokine assays were performed essentially as described for the proliferation assay. Duplicate cultures were stimulated with MOG peptide $(5 \mu \mathrm{g} / \mathrm{ml})$. Culture supernatants were collected at $48 \mathrm{~h}$ for use in cytokine ELISAs. ELISA kits for TNF- $\alpha$, IFN- $\gamma$, IL-4, IL-2, IL-17 and TGF- $\beta 1$ were purchased from R\&D Systems. Each assay was performed according to the manufacturer's instructions. Cytokine production by cultures of CD11d deficient cells is reported as a percentage of the wild-type cell production. The data are pooled from two separate experiments.

\section{Statistical Analysis}

Statistical significance between control and CD11d ${ }^{-/-}$mice for active EAE experiments was calculated using the Mann-Whitney $U$ test. Statistical significance in the proliferation, compensation analysis and cytokine production assays was tested using the student's $t$ test. All statistical analysis was done using Prism software v.4 (GraphPad).

\section{Results}

\section{CD11d-deficiency does not alter the disease course or cellular infiltration of active EAE}

To assess the role of $\mathrm{CD} 11 \mathrm{~d}^{-/-}$in EAE, we performed active EAE using $\mathrm{MOG}_{35-55}$ peptide. We induced EAE in control and CD11 $\mathrm{d}^{-/-}$mice and followed the course of disease for 29 days. The $\mathrm{CD} 11 \mathrm{~d}^{-/-}$mice presented with a phenotype remarkably similar to the wild-type mice as shown in Figure 1. The deletion of CD11 $\mathrm{d}^{-/-}$does not alter the onset (15 days vs. 14 days; Table 1 ), incidence (100\% for both groups) or the severity of disease as determined by cumulative disease index (CDI) for each group (46.5 vs. 45.6; Table 1). We next determined if the extent of cellular infiltrate was similar between the two groups of mice. For these studies, we induced active EAE and isolated spinal cords 10 and 21 days later. Leukocytes were isolated from spinal cords as described in Materials and Methods and analyzed for total leukocyte infiltration 
$\left(\mathrm{CD} 45^{+}\right.$cells) and for $\mathrm{T}$ cell subsets $\left(\mathrm{CD} 4^{+}\right.$and $\left.\mathrm{CD} 8^{+}\right)$. We observed essentially identical infiltration of $\mathrm{CD} 5^{+}$cells in both groups of mice at day 10 (Figure 2A) and at later time points (data not shown). Neutrophil $\left(\mathrm{Gr}-1^{+}\right.$cells) and macrophage $\left(\mathrm{CD} 11 \mathrm{~b}^{+}\right)$cells) infiltration was also not significantly different ( $p>0.05$, student's $t$ test) between wild type and CD $11 \mathrm{~d}^{-/-}$mice (data not shown). To determine if CD11 $\mathrm{d}^{-/-} \mathrm{T}$ cells infiltrated the CNS to a similar extent as T cells from wild type mice, we isolated cells from spinal cords of control and CD11 $\mathrm{d}^{-/-}$mice with active EAE and analyzed for the presence of $\mathrm{CD} 4^{+}$and $\mathrm{CD} 8^{+} \mathrm{T}$ cells. At day 10 , the composition of the $\mathrm{T}$ cell infiltrate in $\mathrm{CD} 11 \mathrm{~d}^{-/-}$mice was not significantly different from that of wild type mice (Figure $2 \mathrm{~B}, \mathrm{p}>0.05$, student's t test). On Day 21 post-immunization, the spinal cords of control and $\mathrm{CD} 11 \mathrm{~d}^{-/-}$mice contained similar numbers of $\mathrm{CD} 4^{+} \mathrm{T}$ cells $(3.3 \%$ and $5.5 \%$ respectively), while $\mathrm{CD} 11 \mathrm{~d}^{-/-}$mice had $\sim 2.5$-fold more $\mathrm{CD}^{+} \mathrm{T}$ cells than control mice (4.4\% and $1.7 \%$, respectively; Figure 2B). The difference in the numbers of $\mathrm{CD} 4^{+} \mathrm{T}$ cells between the two groups was not statistically significant ( $p>0.05$, student's $t$ test). To further characterize the cellular infiltrate in $\mathrm{CD} 11 \mathrm{~d}^{-/-}$versus wild type mice, we examined for the production of intracellular TNF- $\alpha$ and IFN- $\gamma$ in the $\mathrm{CD}^{+} \mathrm{T}$ cell population at days 10 and 21. Wild type and CD11 ${ }^{-/-} \mathrm{CD} 4{ }^{+} \mathrm{T}$ cells produced comparable amounts of TNF- $\alpha$ at day 10 of active EAE (Figure 3 ). $\mathrm{CD} 4^{+} \mathrm{T}$ cells from $\mathrm{CD} 11 \mathrm{~d}^{-/-}$mice produce modestly elevated levels of IFN- $\gamma$ early in disease compared to wild type mice, however, by day 21 , both wild type and CD $11 \mathrm{~d}^{-/-}$T cells produce equivalent amounts of IFN- $\gamma$ and very little TNF- $\alpha$ (Figure 3 ). None of the differences in cytokines produced by $\mathrm{CD} 4+\mathrm{T}$ cells between the two groups of mice was significantly different ( $p>0.05$, student's $t$ test).

\section{Splenic CD11 $\mathrm{d}^{-/-} \mathrm{T}$ cells and macrophages express comparable levels of $\beta_{2}$-integrins compared to wild type cells}

To determine if the expression of the remaining $\beta_{2}$-integrin family members may have changed such that they might compensate for the loss of CD11d, we isolated T cells and macrophages from spleen and lymph nodes from $\mathrm{CD} 11 \mathrm{~d}^{-/-}$and wild type mice at day 21 post-immunization. We observed no statistically significant differences in the expression of CD11a-c on T cells from spleen or lymph nodes between CD11 $\mathrm{d}^{-/-}$and wild type mice (Table 2). In contrast, CD11b and CD11c expression on CD11 $\mathrm{d}^{-/}$-macrophages was significantly lower than that seen on control macrophages. There were no other significant changes in expression of the $\beta_{2}$-integrins on macrophages isolated from CD11 $\mathrm{d}^{-/-}$and wild type mice (table 2 ).

\section{Splenic CD11d ${ }^{-/-}$T cells show no proliferative deficits or differences in cytokine production compared to wild type $T$ cells}

We next looked for differences in the proliferative capacity and cytokine profile of $\mathrm{T}$ cells isolated from the spleens of $\mathrm{CD} 11 \mathrm{~d}^{-/-}$and wild type mice. An in-vitro proliferation assay was performed as described previously (Bullard et al., 2005). Proliferation of MOG-sensitized T cells from wild type and CD11 $\mathrm{d}^{-/-}$mice did not vary significantly ( $\mathrm{p}>0.05$, student's $\mathrm{t}$ test) when restimulated with various concentrations of MOG peptide (Figure 4). We also examined for cytokine production in MOG-sensitized splenic T cells from wild type and CD11 $\mathrm{d}^{-/-}$mice. No significant differences were observed in the levels of IFN- $\gamma$, TNF- $\alpha$, IL-2, IL-17, IL-4, or TGF- $\beta 1$ between the two groups of mice (Figure 5).

\section{Discussion}

Members of the $\beta_{2}$-integrin family of adhesion molecules are primarily known for their roles in leukocyte trafficking and, in the case of CD11b and CD11c, phagocytosis (reviewed in (Mayadas and Cullere, 2005; Underhill and Ozinsky, 2002; von Andrian and Mackay, 2000)). Although the results have often been contradictory, inhibition of $\beta_{2}$-integrin functions via treatment with antibody generally results in a better disease outcome regardless of the model system employed. This is also true in the CNS, where anti-CD11a and anti-CD11b treatment 
reduced clinical signs of disease, cellular infiltration and phagocytosis of myelin (reviewed in (Barnum, 2001; Engelhardt, 2006)). Surprisingly the results reported in this study indicate that CD11d, unlike the other members of the $\beta_{2}$-integrin family, is not required for development or progression of EAE. In contrast, in a SCI model system employing spinal cord transection, inhibition of CD11d through the use of anti-CD11d monoclonal antibodies, partially prevented the infiltration of neutrophils and macrophages (Mabon et al., 2000). The long-term effectiveness of antibody treatment was not assessed with respect to cellular infiltration, neuronal survival or functional outcome, and the protective effect was attributed largely to disruption of neutrophil interaction with VCAM-1 on the vascular endothelium (Mabon et al., 2000). More recent SCI studies, in which the spinal cord was injured by compression (as opposed to transection), demonstrated not only reduced cellular infiltration but also reduced secondary injury and improved functional outcome for up to 12 weeks post treatment (Gris et al., 2005; Gris et al., 2004). Importantly, anti-CD11d treated mice had reduced myelin loss and more rapid remyelination compared to control mice (Gris et al., 2004). Based on the treatment regimen in these studies ( 3 injections in $48 \mathrm{hrs)}$ ) and the long-term improved outcome, it is clear that transient inhibition of leukocyte infiltration with anti-CD11d, during the acute phase response, provides significant neuroprotection.

The effect of blocking or deleting CD11d with respect to $\mathrm{T}$ cell infiltration has not been previously examined. In the present study we observed that both $\mathrm{CD} 4^{+}$and $\mathrm{CD} 8^{+} \mathrm{T}$ cells readily infiltrated the spinal cords of CD11 d $\mathrm{d}^{-/-}$mice during EAE (Figure 2B). In fact, our data indicate that greater frequencies of both $\mathrm{T}$ cell subsets migrate into the spinal cords of $\mathrm{CD} 11 \mathrm{~d}^{-/-}$mice during EAE compared to control mice. This data combined with the observation that CD45+ cells (as representative of the total leukocyte infiltrate) also traffic readily into the spinal cords of $\mathrm{CD} 11 \mathrm{~d}^{-/-}$mice, indicates that CD11d is not required for CNS infiltration in EAE. Although it is possible that other $\beta_{2}$-integrins or members of other integrin families compensate for the loss of CD11d under these circumstances, we did not observe this by flow cytometry (Table 2 ) and, deletion of any of the remaining $\beta_{2}$-integrin $\alpha$-chains results in significant attenuation of EAE ((Bullard et al., 2005), J. Hu, D. Bullard and S.R. Barnum, unpublished observations).

Aside from cellular trafficking, it is possible that deletion of CD11d could affect $\mathrm{T}$ cell proliferation and effector functions in a way that would alter the course of EAE relative to control mice. However, we observed no difference in antigen-specific $\mathrm{T}$ cell proliferation in $\mathrm{CD} 11 \mathrm{~d}^{-/-}$and control mice (Figure 3), indicating that there is no intrinsic proliferative defect in the absence of CD11d. Wu and colleagues demonstrated that CD11d ${ }^{-/-} \mathrm{T}$ cells proliferate comparably to wild type $\mathrm{T}$ cells when the $\mathrm{T}$ cell receptor is bypassed on treatment with PMA and ionomycin (Wu et al., 2004). However, in the same study, it was shown that CD11 $\mathrm{d}^{-/-} \mathrm{T}$ cells proliferate poorly on treatment with PHA, ConA and several superantigens including SEA, SEB and SEE (Wu et al., 2004). The reason(s) for these differences in proliferative capacity remain unclear. Similar to the proliferation assays using $\mathrm{T}$ cells from $\mathrm{CD} 11 \mathrm{~d}^{-/-}$mice, there were no differences in production of IFN- $\gamma$ and TNF- $\alpha$, in T cells isolated from the spinal cords, compared to control mice. In contrast, splenic $\mathrm{T}$ cells from $\mathrm{CD} 11 \mathrm{~d}^{-/-}$mice produced two-fold greater levels of IFN- $\gamma$, but lower levels of TNF- $\alpha$ compared to control mice. The reasons for differential production of cytokines in these two tissue sites is unclear but suggests that evaluation of $\mathrm{T}$ cell cytokine production in the spleen, is not necessarily representative of cytokine production at sites of demyelination.

Adhesion molecules and their respective ligands represent an attractive therapeutic target for demyelinating disease. Inhibition of effector lymphocyte and phagocytic cell trafficking into the CNS by inhibiting adhesion molecule interactions provides significant protection from clinical disease as reported in animal models and clinical trials (Bullard et al., 2005; Cannella et al., 1993; Engelhardt, 2006; Gordon et al., 1995; Miller et al., 2003; Nataf et al., 2000; Welsh et al., 1993; Willenborg et al., 1996). Although this strategy has proven effective for many 
adhesion molecules, it is not uniformly effective. For example, deletion of $\mathrm{E}$ and $\mathrm{P}$ selectins and PSGL-1 has no effect on the outcome of EAE (Brocke et al., 1999; Engelhardt, 1997; Engelhardt et al., 2005; Osmers et al., 2005). The failure to protect against demyelinating disease through targeted inhibition of these molecules is likely due to redundancy of function for some family members through the utilization of unexpected receptor/ligand pairs or signaling pathways (Fagerholm et al., 2004; Hynes, 2002; Richter et al., 1990). Which of these possibilities account for the results we report here for CD11d remains to be fully explored. Our results support growing evidence that $\beta_{2}$-integrins participate in unique rather than highly overlapping functions and indicate that successful therapeutic targeting even of closely related family members might be disease-specific.

\section{Acknowledgments}

This work was supported by a grant from the NIH (NS46032) to S.R. Barnum. J.E. Adams is supported by a training grant from the NIH (GM08111-18).

\section{References}

Archelos JJ, Previtali SC, Hartung HP. The role of integrins in immune-mediated diseases of the nervous system. Trends Neurosci 1999;22:30-38. [PubMed: 10088997]

Bao F, Chen Y, Dekaban GA, Weaver LC. An anti-CD11d integrin antibody reduces cyclooxygenase-2 expression and protein and DNA oxidation after spinal cord injury in rats. J Neurochem 2004;90:11941204. [PubMed: 15312174]

Barnum, SR. The complement system in demyleinating disease: new insights from transgenic and complement-deficient mice. In: Bondy, SC.; Campbell, A., editors. Inflammatory Events in Neurodegeneration. Prominent Press; Scottsdale: 2001. p. 139-156.

Brocke S, Piercy C, Steinman L, Weissman IL, Veromaa T. Antibodies to CD44 and integrin alpha4, but not L-selectin, prevent central nervous system inflammation and experimental encephalomyelitis by blocking secondary leukocyte recruitment. Proc Natl Acad Sci U S A 1999;96:6896-6901. [PubMed: 10359810]

Bruck W. The role of macrophages in Wallerian degeneration. Brain Pathol 1997;7:741-752. [PubMed: 9161725]

Bruck W, Friede RL. Anti-macrophage CR3 antibody blocks myelin phagocytosis by macrophages in vitro. Acta Neuropathol 1990;80:415-418. [PubMed: 2239153]

Bullard DC, Hu X, Schoeb TR, Axtell RC, Raman C, Barnum SR. Critical requirement of CD11b (Mac-1) on T cells and accessory cells for development of experimental autoimmune encephalomyelitis. J Immunol 2005;175:6327-6333. [PubMed: 16272284]

Butcher EC, Williams M, Youngman K, Rott L, Briskin M. Lymphocyte trafficking and regional immunity. Adv Immunol 1999;72:209-253. [PubMed: 10361577]

Campbell JJ, Hedrick J, Zlotnik A, Siani MA, Thompson DA, Butcher EC. Chemokines and the arrest of lymphocytes rolling under flow conditions. Science 1998;279:381-384. [PubMed: 9430588]

Cannella B, Cross AH, Raine CS. Anti-adhesion molecule therapy in experimental autoimmune encephalomyelitis. J Neuroimmunol 1993;46:43-55. [PubMed: 8103061]

Engelhardt B. Immune cell migration across the blood-brain barrier: molecular mechanisms and therapeutic targeting. Future Neurol 2006;1:47-56.

Engelhardt B, Vestweber D, Hallmann R, Schulz M. E- and P-selectin are not involved in the recruitment of inflammatory cells across the blood-brain barrier in experimental autoimmune encephalomyelitis. Blood 1997;90:4459-4472. [PubMed: 9373256]

Engelhardt B, Kempe B, Merfeld-Clauss S, Laschinger M, Furie B, Wild MK, Vestweber D. P-selectin glycoprotein ligand 1 is not required for the development of experimental autoimmune encephalomyelitis in SJL and C57BL/6 mice. J Immunol 2005;175:1267-1275. [PubMed: 16002731]

Engelhardt B, Laschinger M, Schulz M, Samulowitz U, Vestweber D, Hoch G. The development of experimental autoimmune encephalomyelitis in the mouse requires alpha4-integrin but not alpha4beta7-integrin. J Clin Invest 1998;102:2096-2105. [PubMed: 9854045] 
Fagerholm SC, Hilden TJ, Gahmberg CG. P marks the spot: site-specific integrin phosphorylation regulates molecular interactions. Trends Biochem Sci 2004;29:504-512. [PubMed: 15337124]

Gordon EJ, Myers KJ, Dougherty JP, Rosen H, Ron Y. Both anti-CD11a (LFA-1) and anti-CD11b (MAC-1) therapy delay the onset and diminish the severity of experimental autoimmune encephalomyelitis. J Neuroimmunol 1995;62:153-160. [PubMed: 7499503]

Gris D, Marsh DR, Dekaban GA, Weaver LC. Comparison of effects of methylprednisolone and antiCD11d antibody treatments on autonomic dysreflexia after spinal cord injury. Exp Neurol 2005;194:541-549. [PubMed: 15890340]

Gris D, Marsh DR, Oatway MA, Chen Y, Hamilton EF, Dekaban GA, Weaver LC. Transient blockade of the CD11d/CD18 integrin reduces secondary damage after spinal cord injury, improving sensory, autonomic, and motor function. J Neurosci 2004;24:4043-4051. [PubMed: 15102919]

Huitinga I, Damoiseaux JG, Dopp EA, Dijkstra CD. Treatment with anti-CR3 antibodies ED7 and ED8 suppresses experimental allergic encephalomyelitis in Lewis rats. Eur J Immunol 1993;23:709-715. [PubMed: 8449218]

Hynes RO. Integrins: bidirectional, allosteric signaling machines. Cell 2002;110:673-687. [PubMed: 12297042]

Kent SJ, Karlik SJ, Cannon C, Hines DK, Yednock TA, Fritz LC, Horner HC. A monoclonal antibody to alpha 4 integrin suppresses and reverses active experimental allergic encephalomyelitis. $\mathbf{J}$ Neuroimmunol 1995;58:1-10. [PubMed: 7730443]

Mabon PJ, Weaver LC, Dekaban GA. Inhibition of monocyte/macrophage migration to a spinal cord injury site by an antibody to the integrin alphaD: a potential new anti-inflammatory treatment. Exp Neurol 2000;166:52-64. [PubMed: 11031083]

Mayadas TN, Cullere X. Neutrophil beta2 integrins: moderators of life or death decisions. Trends Immunol 2005;26:388-395. [PubMed: 15922663]

Miller DH, Khan OA, Sheremata WA, Blumhardt LD, Rice GP, Libonati MA, Willmer-Hulme AJ, Dalton CM, Miszkiel KA, O'Connor PW. A controlled trial of natalizumab for relapsing multiple sclerosis. N Engl J Med 2003;348:15-23. [PubMed: 12510038]

Myers KJ, Witchell DR, Graham MJ, Koo S, Butler M, Condon TP. Antisense oligonucleotide blockade of alpha 4 integrin prevents and reverses clinical symptoms in murine experimental autoimmune encephalomyelitis. J Neuroimmunol 2005;160:12-24. [PubMed: 15710453]

Nataf S, Carroll SL, Wetsel RA, Szalai AJ, Barnum SR. Attenuation of experimental autoimmune demyelination in complement-deficient mice. J Immunol 2000;165:5867-5873. [PubMed: 11067947]

Osmers I, Bullard DC, Barnum SR. PSGL-1 is not required for development of experimental autoimmune encephalomyelitis. J Neuroimmunol 2005;166:193-196. [PubMed: 16005524]

Richter J, Ng-Sikorski J, Olsson I, Andersson T. Tumor necrosis factor-induced degranulation in adherent human neutrophils is dependent on CD11b/CD18-integrin-triggered oscillations of cytosolic free $\mathrm{Ca}^{2+}$ Proc Natl Acad Sci 1990;87:9472-9476. [PubMed: 1979172]

Saville LR, Pospisil CH, Mawhinney LA, Bao F, Simedrea FC, Peters AA, O’Connell PJ, Weaver LC, Dekaban GA. A monoclonal antibody to CD11d reduces the inflammatory infiltrate into the injured spinal cord: a potential neuroprotective treatment. J Neuroimmunol 2004;156:42-57. [PubMed: 15465595]

Shanley TP, Warner RL, Crouch LD, Dietsch GN, Clark DL, O’Brien MM, Gallatin WM, Ward PA. Requirements for alpha d in IgG immune complex-induced rat lung injury. J Immunol 1998;160:1014-1020. [PubMed: 9551942]

Smith ME. Phagocytosis of myelin in demyelinative disease: a review. Neurochem Res 1999;24:261268. [PubMed: 9972873]

Sospedra M, Martin R. Immunology of multiple sclerosis *. Annu Rev Immunol 2005;23:683-747. [PubMed: 15771584]

Szalai AJ, Nataf S, Hu XZ, Barnum SR. Experimental allergic encephalomyelitis is inhibited in transgenic mice expressing human C-reactive protein. J Immunol 2002;168:5792-5797. [PubMed: 12023381]

Underhill DM, Ozinsky A. Phagocytosis of microbes: complexity in action. Annu Rev Immunol 2002;20:825-852. [PubMed: 11861619] 
von Andrian UH, Mackay CR. T-cell function and migration. Two sides of the same coin. N Engl J Med 2000;343:1020-1034. [PubMed: 11018170]

Welsh CT, Rose JW, Hill KE, Townsend JJ. Augmentation of adoptively transferred experimental allergic encephalomyelitis by administration of a monoclonal antibody specific for LFA-1 alpha. J Neuroimmunol 1993;43:161-167. [PubMed: 7681447]

Willenborg DO, Staykova MA, Miyasaka M. Short term treatment with soluble neuroantigen and antiCD11a (LFA-1) protects rats against autoimmune encephalomyelitis: treatment abrogates autoimmune disease but not autoimmunity. J Immunol 1996;157:1973-1980. [PubMed: 8757317]

Wu H, Rodgers JR, Perrard XY, Perrard JL, Prince JE, Abe Y, Davis BK, Dietsch G, Smith CW, Ballantyne CM. Deficiency of CD11b or CD11d results in reduced staphylococcal enterotoxininduced T cell response and T cell phenotypic changes. J Immunol 2004;173:297-306. [PubMed: 15210787]

Yednock TA, Cannon C, Fritz LC, Sanchez-Madrid F, Steinman L, Karin N. Prevention of experimental autoimmune encephalomyelitis by antibodies against $\alpha 4 \beta 1$ integrin. Nature 1992;356:63-66. [PubMed: 1538783] 


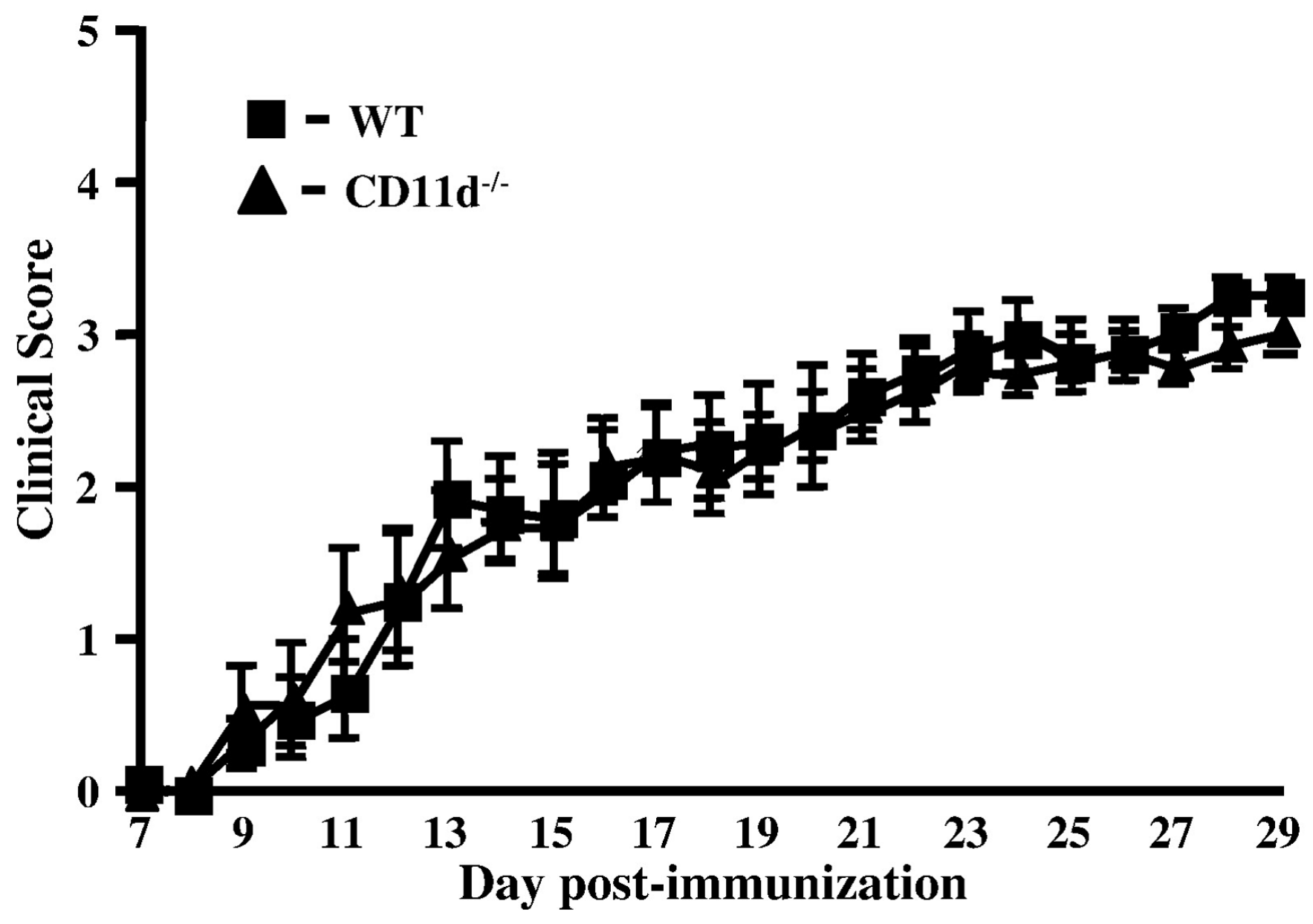

Figure 1.

The clinical course of MOG-induced EAE in wild-type mice and CD11 $\mathrm{d}^{-/}$mice is identical. Active EAE was induced and symptoms were scored as described in the materials and methods. Results shown are the daily mean clinical scores for wild type $(\mathrm{n}=11)$ and $\mathrm{CD} 11 \mathrm{~d}^{-/-}$mice $(\mathrm{n}=11)$ from 3 experiments. 
A.

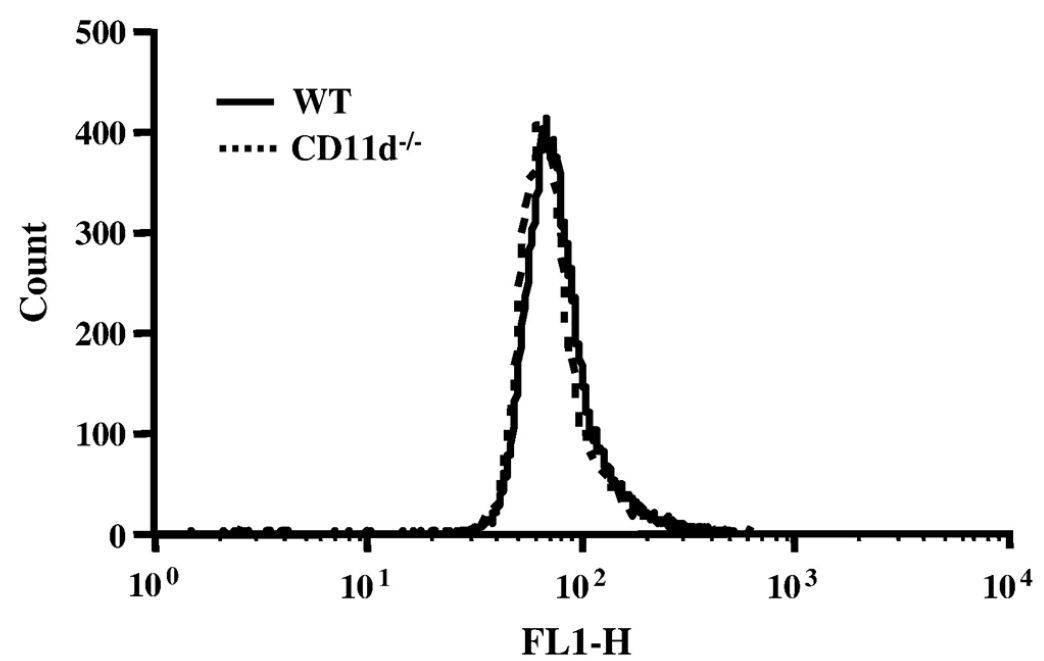

B.

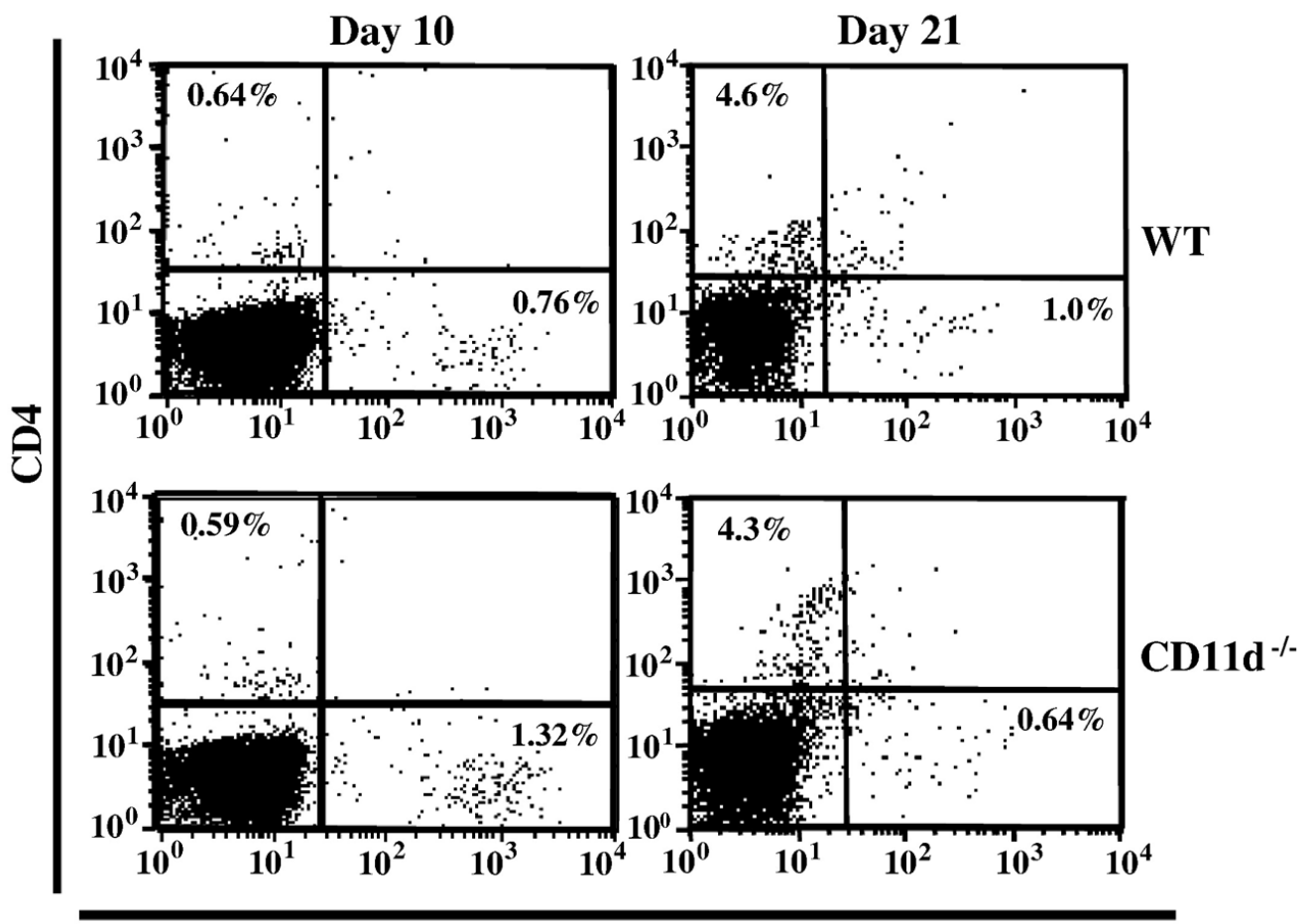

\section{CD8}

Figure 2.

Leukocyte subsets in spinal cord of control and CD11 $\mathrm{d}^{-/-}$deficient mice with EAE are identical. Leukocytes isolated from spinal cords of control and CD11 $\mathrm{d}^{-/-}$mice as described in Materials and Methods were immunostained for CD4, CD8 and CD45. A) The level of CD45 cells infiltrating the spinal cords of wild type $(n=5)$ and $C D 11 d^{-/-}(n=6)$ mice 10 days postimmunization are identical. B) The percentage of $\mathrm{CD}^{+}{ }^{+} \mathrm{T}$ cells in the spinal cords of wild type and $\mathrm{CD} 11 \mathrm{~d}^{-/-}$mice at days $10(\mathrm{n}=5$ and 6 , respectively) and 21 ( $\mathrm{n}=4$ and 5, respectively) postimmunization were nearly identical (upper left quadrant in each panel). The percentage of $\mathrm{CD}^{+} \mathrm{T}$ cells is modestly elevated in $\mathrm{CD} 11 \mathrm{~d}^{-/-}$mice at day 21 post-immunization compared 
to wild type mice (lower right quadrant). The results shown are from cells pooled within each group of mice and a representative experiment is shown. 


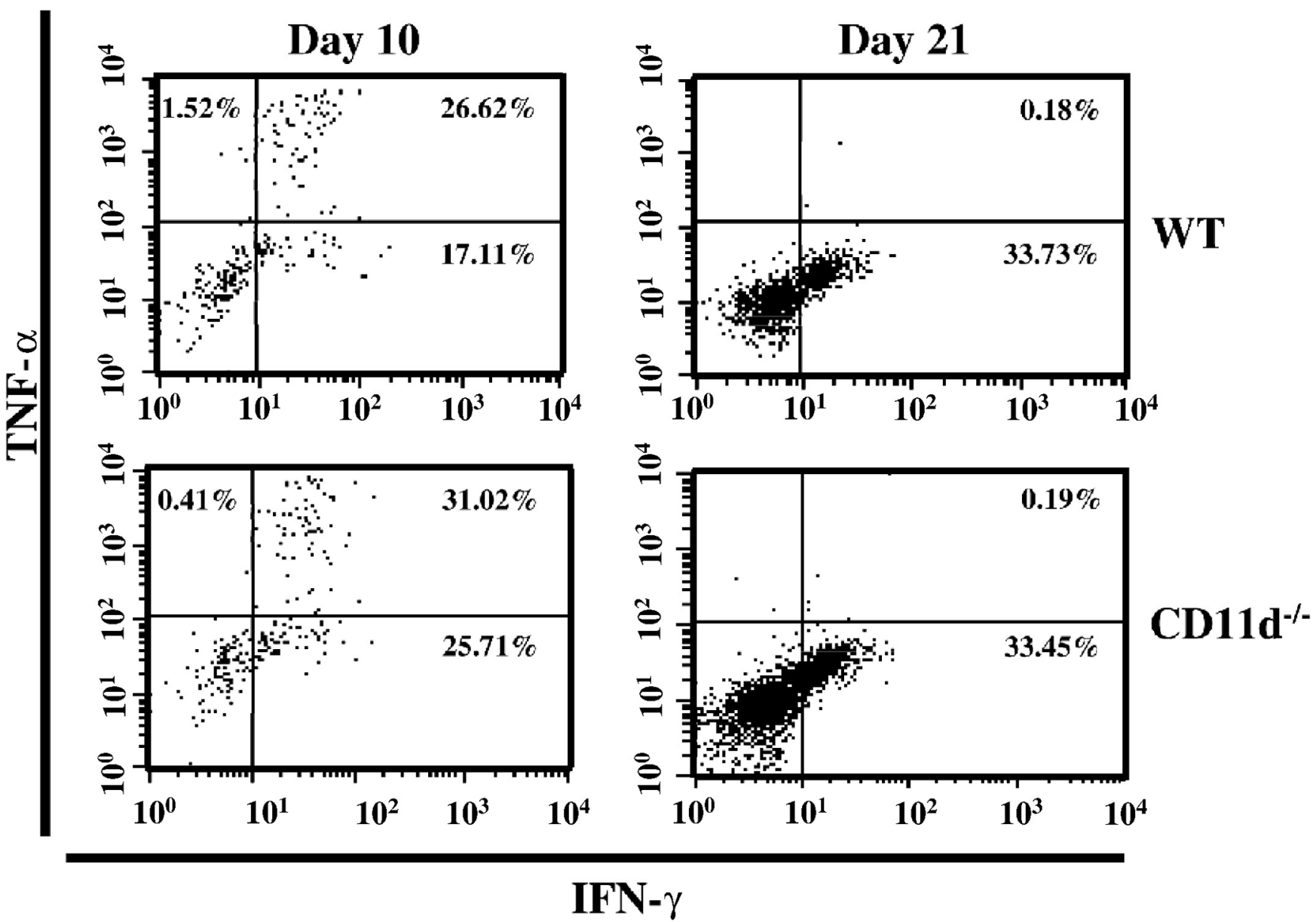

Figure 3.

Intracellular levels of TNF- $\alpha$ and IFN- $\gamma$ are identical in spinal cord-derived CD4 ${ }^{+} \mathrm{T}$ cells from wild type and CD $11 \mathrm{~d}^{-/-}$mice with active EAE. CD4 ${ }^{+} \mathrm{T}$ cells were isolated from the spinal cords of wild type and CD $11 \mathrm{~d}^{-/-}$mice at 10 ( $\mathrm{n}=5$ and 6, respectively) and 21 days ( $\mathrm{n}=4$ and 5, respectively) post-immunization and stained for intracellular TNF- $\alpha$ and IFN- $\gamma$ as described in Materials and Methods. IFN- $\gamma$ levels were modestly elevated at day 10 in CD $11 \mathrm{~d}^{-/-}$mice compared to wild type mice. Cytokine levels were similar for both groups at day 21 . The results shown are from cells pooled within each group of mice. 


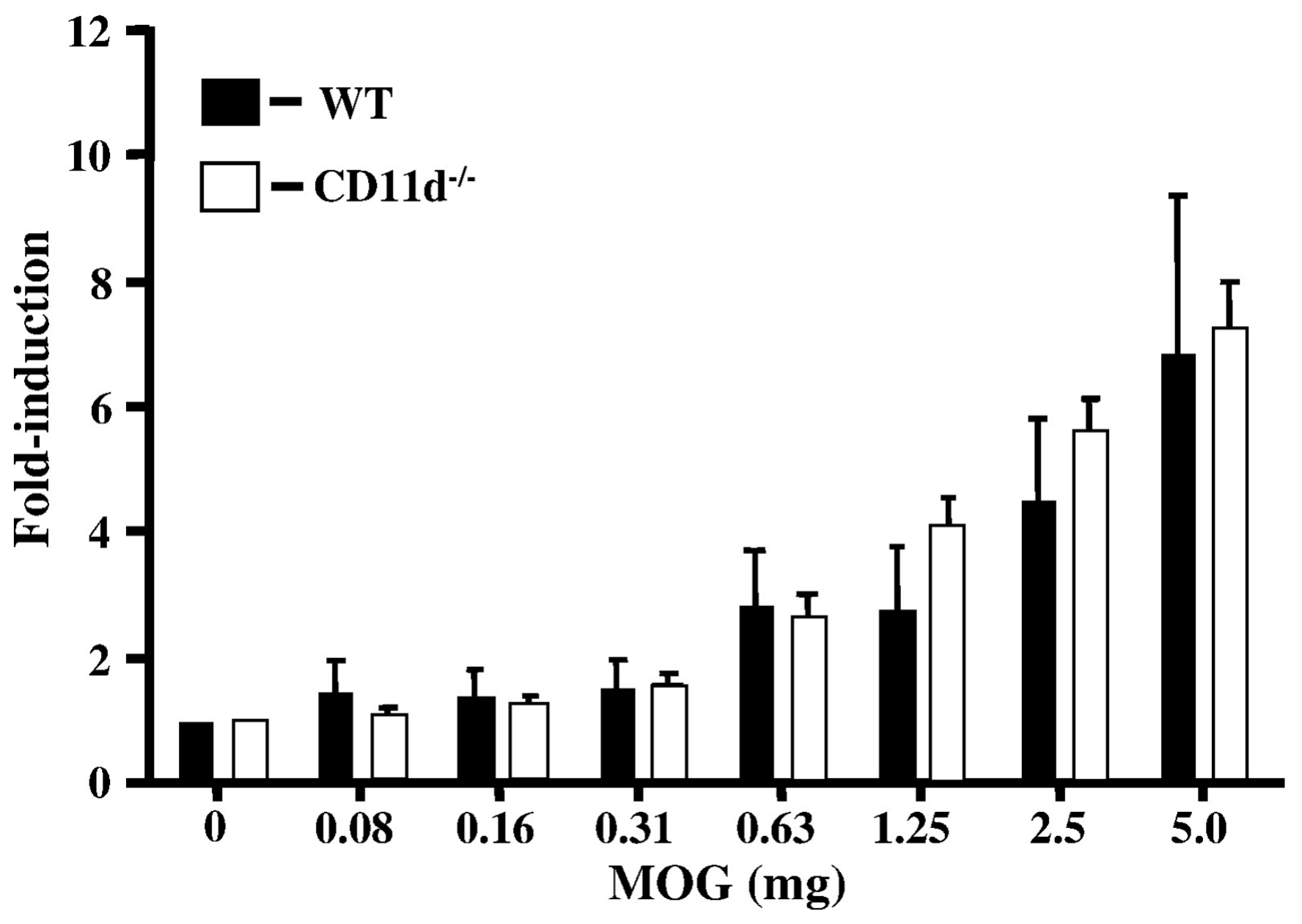

Figure 4.

CD $11 \mathrm{~d}^{-/-} \mathrm{T}$ cells proliferate comparably to wild-type T cells. Encephalitogenic T cells enriched by nylon wool adherence from the spleens of wild type $(n=4)$ or CD11d $\mathrm{d}^{-/-}(n=4)$ mice with active EAE were co-cultured with irradiated splenic APCs plus MOG peptide. Cells were pulsed with $\left[{ }^{3} \mathrm{H}\right]$ thymidine and harvested at $18 \mathrm{~h}$ for determination of radioisotope incorporation. The results shown are from two experiments and are expressed as the mean \pm SEM of fold induction of $\mathrm{T}$ cell proliferation relative to background proliferation. 


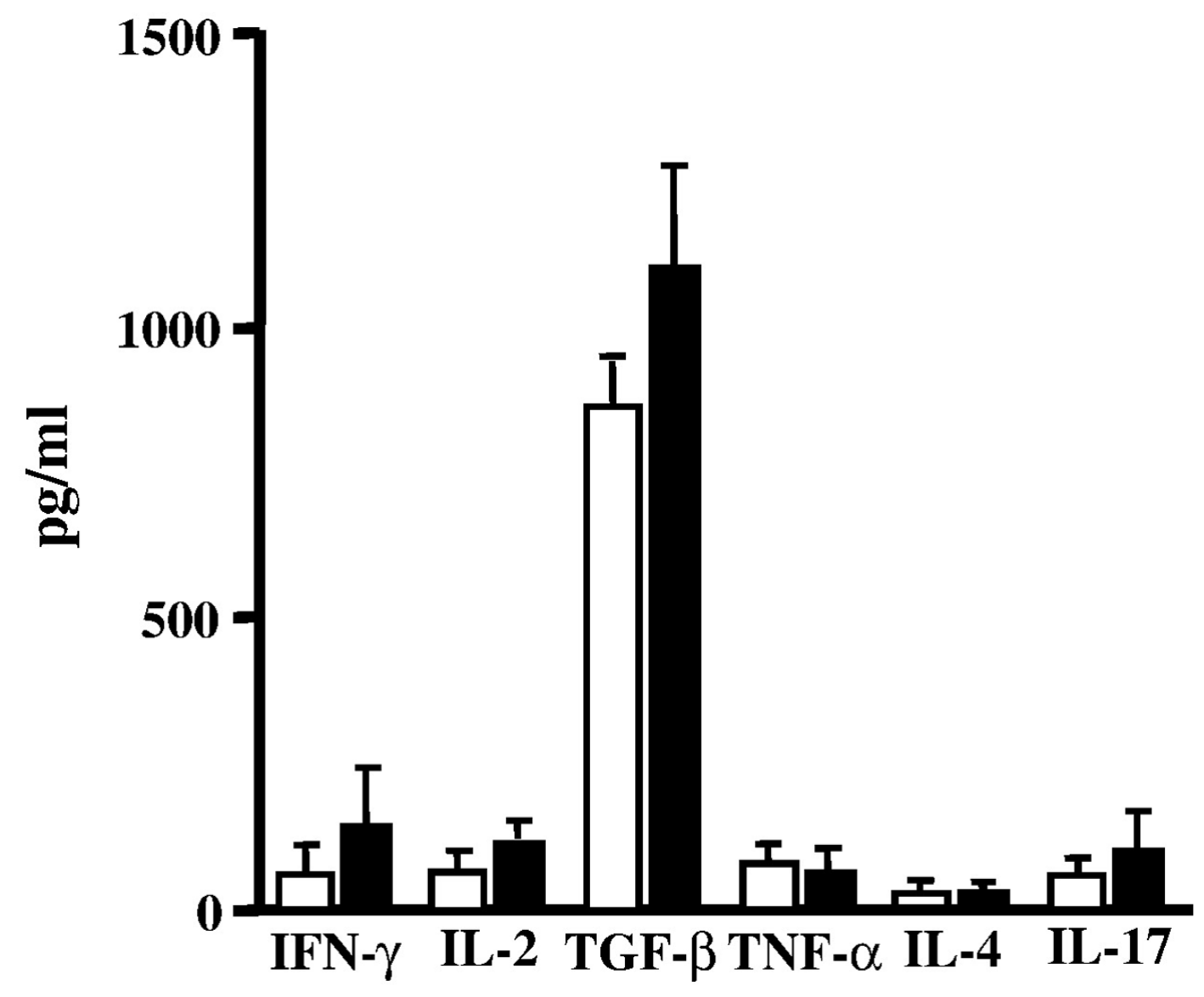

Figure 5.

The cytokine repertoire of CD $11 \mathrm{~d}^{-/-} \mathrm{T}$ cells is not significantly altered compared to wild-type $\mathrm{T}$ cells during EAE. Encephalitogenic T cells enriched by nylon wool adherence from the spleens of wild-type $(n=6)$ or CD11d $\mathrm{d}^{-/-}(\mathrm{n}=6)$ mice with active EAE were co-cultured with irradiated splenic APCs and restimulated with MOG peptide. Supernatants were collected $48 \mathrm{~h}$ after stimulation and assayed by ELISA to quantitate production of each cytokine. The production of each cytokine for both CD11 $\mathrm{d}^{-/}$and wild type mice is presented as the mean \pm S.D. in $\mathrm{pg} / \mathrm{ml}$. The data are the mean of two experiments. 
Table 1

EAE Symptoms in wild type and CD11d-deficient mice.

\begin{tabular}{cccc}
\hline & CDI $^{\boldsymbol{A}}$ & Disease Onset $^{\boldsymbol{B}}$ & 100 \\
\hline Wild type $\mathrm{n}=11$ & 46.5 & $15 \mathrm{~d}$ Incidence & 100 \\
$\mathrm{CD} 11 \mathrm{~d}^{-/-} \mathrm{n}=11$ & 45.6 & $14 \mathrm{~d}$ & \\
\hline${ }^{A}$ Cumulative Disease Index is the mean of the sum of daily clinical scores observed between days 7 and 29. & \\
${ }^{B}$ Disease onset is defined as the first day of two consecutive days with a clinical score of two or more. \\
${ }_{\text {Disease incidence is defined as the percent of mice that displayed any clinical signs of disease. }}$
\end{tabular}


Table 2

Changes in expression of $\beta_{2}$-integrins on T cells and macrophages in CD11d-deficient mice during EAE

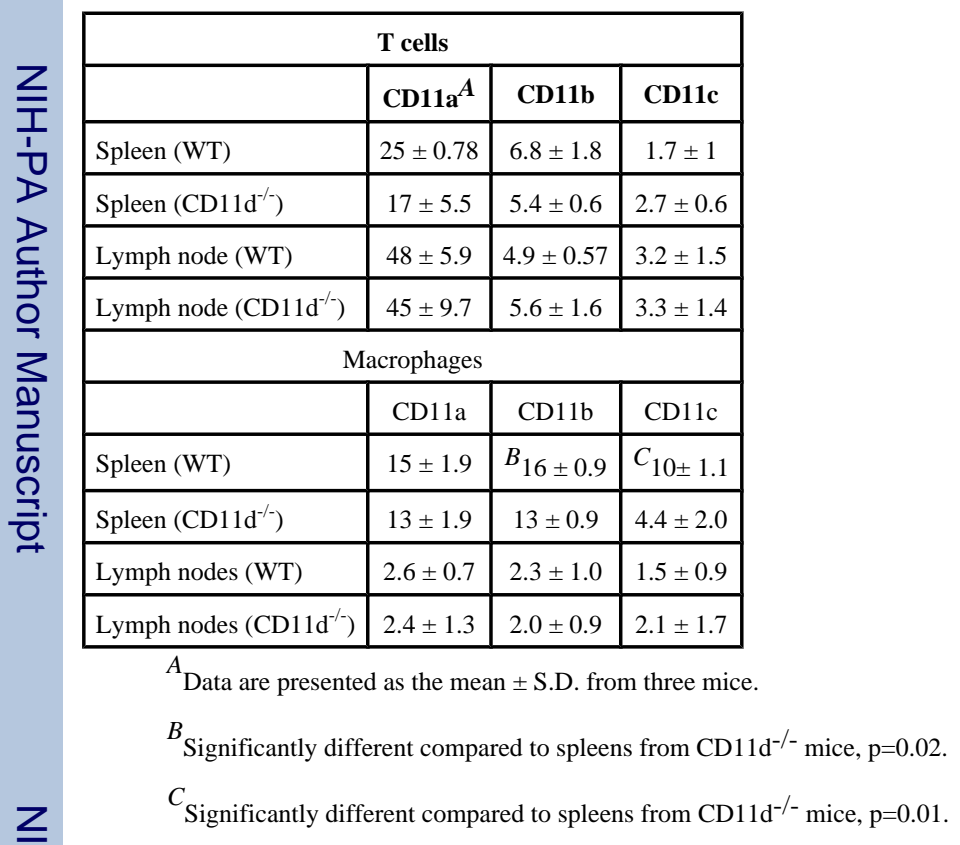

